more easily allow the divergence of subunits and, as a consequence, the diversification of the complex's function.

\section{ACKNOWLEDGMENTS}

The author thanks R. Raijmakers for helpful suggestions and assistance in preparation of the figure and $\mathrm{E}$. Conti, B. Prasad and K. Reinisch for kindly providing the coordinates of the complexes shown in the figure.

1. Raijmakers, R., Schilders, G. \& Pruijn, G.J. Eur. J. Cell Biol. 83, 175-183 (2004).

2. Lorentzen, E., Walter, P., Fribourg, S., EvguenievaHackenberg, E. \& Conti, E. Nat. Struct. Mol. Biol. 12, 575-587 (2005).

3. Mitchell, P. \& Tollervey, D. Nat. Struct. Biol. 7, 843846 (2000).

4. Symmons, M.F., Jones, G.H. \& Luisi, B.F. Struct. Fold. Des. 8, 1215-1226 (2000).
5. Symmons, M.F., Williams, M.G., Luisi, B.F., Jones, G.H. \& Carpousis, A.J. Trends Biochem. Sci. 27, 11-18 (2002).

6. Aloy, P. et al. EMBO Rep. 3, 628-635 (2002).

7. Lehner, B. \& Sanderson, C.M. Genome Res. 14, 13151323 (2004).

8. Estevez, A.M., Lehner, B., Sanderson, C.M., Ruppert, T. \& Clayton, C. J. Biol. Chem. 278, 34943-34951 (2003).

9. Raijmakers, R., Egberts, W.V., van Venrooij, W.J. \& Pruijn, G.J. J. Mol. Biol. 323, 653-663 (2002).

10. Evguenieva-Hackenberg, E., Walter, P., Hochleitner, E., Lottspeich, F. \& Klug, G. EMBO Rep. 4, 889-893 (2003).

11. LaCava, J. et al. Cell, 121, 713-724 (2005).

12. Wyers, F. et al. Cell, 121, 725-737 (2005).

13. Dreyfus, M. \& Regnier, P. Cell 111, 611-613 (2002).

14. Valentine, R.C., Thang, M.N. \& Grunberg-Manago, M. J. Mol. Biol. 39, 389-391 (1969).

15. Choi, J.M., Park, E.Y., Kim, J.H., Chang, S.K. \& Cho, Y. J. Biol. Chem. 279, 755-764 (2004).
16. Monzingo, A.F., Gao, J., Qiu, J., Georgiou, G. \& Robertus, J.D. J. Mol. Biol. 332, 1015-1024 (2003).

17. Kastner, B., Bach, M. \& Luhrmann, R. Proc. Natl. Acad. Sci. USA 87, 1710-1714 (1990).

18. Kambach, C. et al. Cell 96, 375-387 (1999).

19. Toro, I., Basquin, J., Teo-Dreher, H. \& Suck, D. J. Mol. Biol. 320, 129-142 (2002).

20. Toro, I. et al. EMBO J. 20, 2293-2303 (2001).

21. Mura, C., Cascio, D., Sawaya, M.R. \& Eisenberg, D.S. Proc. Natl. Acad. Sci. USA 98, 5532-5537 (2001).

22. Achsel, T. et al. EMBO J. 18, 5789-5802 (1999).

23. Collins, B.M. et al. J. Mol. Biol. 309, 915-923 (2001).

24. Urlaub, H., Raker, V.A., Kostka, S. \& Luhrmann, R. EMBO J. 20, 187-196 (2001).

25. Jayaram, H., Taraporewala, Z., Patton, J.T. \& Prasad, B.V. Nature 417, 311-315 (2002).

26. Stein, A.J., Fuchs, G., Fu, C., Wolin, S.L. \& Reinisch, K.M. Cell 121, 529-539 (2005).

27. Breyer, W.A. \& Matthews, B.W. Protein Sci. 10, 1699 1711 (2001).

\title{
P-bodies take a RISC
}

RNA interference, the RNA-induced silencing complex (RISC), and microribonucleoproteins (miRNPs) have received a lot of attention in the past few years as a means to down regulate gene expression. Double-stranded siRNAs are recognized and unwound by RISC. One strand of siRNA is bound by Argonaute 2 (Ago2), an endonuclease, and this ribonucleic acid complex selects and cleaves the complementary region in the target mRNA. This cleavage results in gene silencing. miRNPs can affect gene expression by inhibiting translation. In this process, micro RNAs (miRNAs) are bound by Ago2 and other related Argonaute proteins, and incorporated into RISC-like complexes in a manner similar to siRNAs. However, miRNA do not form perfect base-pairs with their target mRNA and therefore do not usually elicit Ago2-mediated cleavage of the target. How miRNAs inhibit protein synthesis is not yet clear.

RISC containing miRNA may directly interfere with translation initiation or elongation. Alternatively, RISC might sequester the target mRNA from the translation machinery, perhaps targeting the message to centers of mRNA degradation. These centers, which contain untranslated mRNAs and are sites of mRNA degradation, have been previously observed in yeast and animal cells and are called processing $(P)$ bodies (also known as cytoplasmic bodies, Dcp bodies or GW bodies). In two papers, the Blau group (Nat. Cell Biol. 7, 633-636, 2005) and the Hannon and Parker labs (Nat. Cell Biol. advance online publication, 5 June 2005 doi: 10.1038/ ncb1274) show that Ago2 and related Ago1, Ago3, and Ago4 proteins are localized to P-bodies. The authors determined the location of Ago2 (top panel) and related proteins in the cytoplasm by examining their co-localization with GW182, a protein found in cytoplasmic bodies and involved in mRNA metabolism, and with decapping proteins, Dcp1 and Dcp2, which are found in P-bodies (middle panel). These data link Argonaute proteins and perhaps RISC to centers of RNA turnover.

A simple explanation for Ago2 being in P-bodies is that AgomiRNA complexes target mRNAs to these structures and thereby lead to translation repression and potentially even mRNA degradation. Consistent with this possibility, the Hannon and Parker groups find that miRNA-regulated mRNAs build up in P-bodies whereas Ago2 mutants unable to bind miRNAs do not. The accumulation of Ago2 and miRNA-regulated RNAs depends both on the presence of the small RNA and the correct recognition sites in the target mRNA. Moreover, Sen and Blau have shown that the concentration of Ago2 in foci is sensitive to RNase treatment of the cells before immunofluourescence. In combination, these observations suggest that mRNAs that are translationally repressed by miRNA collect in P-bodies along with Ago2miRNA complexes, and may be targeted there by Argonaute proteins or other components of RISC.

Whether Ago2 permanently resides in the P-bodies or if it is specifically localized to these foci is not yet clear. Data from the Blau lab show that Ago2 is also found in the cytoplasm. Furthermore, the Hannon and Parker groups show that Ago2 mutants that cannot localize to P-bodies can still interact with both Dcp1 and Dcp2. These results suggest that Ago2 may interact with decapping enzymes outside of P-bodies and this interaction could play a role in the targeting of Ago2-miRNA-mRNA complexes to the P-bodies. Further studies are required to determine whether miRNA-mediated translation repression occurs before or after the Ago2-miRNA-mRNA complex is delivered to the P-bodies.
Evelyn Jabri 